\title{
Pengukuran Kinerja Pegawai Dinas Pekerjaan Umum Provinsi Maluku Dalam Pemanfaatan Sistem Informasi Dengan Menggunakan IT Balanced Scorecard
}

\author{
Syeni Novianti Ferdinandus, Augie David Manuputty \\ Fakultas Teknologi Informasi, Sistem Informasi, Universitas Kristen Satya Wacana, Salatiga, Indonesia \\ Email: ${ }^{1} 682014605 @$ student.uksw.edu, ${ }^{2}$ augiemanuputty@gmail.com \\ Submitted: 15/02/2021; Accepted: 04/03/2021; Published: 30/05/2021
}

\begin{abstract}
Abstrak-Dinas pekerjaan umum provinsi Maluku merupakan salah satu badan publik yang mempunyai tugas melaksanakan urusan pemerintah daerah. Tujuan penelitian untuk mengetahui sejauhmana kontribusi dan pemanfaatan melalui aplikasi TI dalam menunjang kebutuhan kinerja pegawai. Penelitian ini menggunakan metode IT Balanced Scorecard sebagai sarana pengukuran yang jelas, memantau dan mengoptimalkan realisasi dari nilai atau manfaat bisnis dan manfaat Teknologi Informasi dimana IT Balanced Scorecard mempunyai 4 perspektif (Perspektif Kontribusi Organisasi, Perspektif Orientasi Pengguna, Perspektif Keunggulan Operasional, dan Perspektif Orientasi Masa Depan). Metode penelitian yang akan digunakan dalam Pengukuran Kinerja Pegawai Dinas Pekerjaan Umum adalah metode mixed methods. Pada penelitian ini pengumpulan data diperoleh melalui wawancara, observasi, dan penyebaran kuesioner ke sejumlah responden yang dipilih berdasarkan kemampuan dan relevan dengan pekerjaan mereka. Penelitian ini memperlihatkan nilai pengukuran Kontribusi Organisasi sebesar 23 persen, Orientasi Pengguna sebesar 19 persen, Operasional sebesar 21 persen, dan Orientasi Masa Depan sebesar 20 persen dan untuk hasil rata-rata dari nilai IT Balanced Scorecard adalah 85 persen. Pada hasil pengukuran pegawai, perspektif tertinggi adalah Kontribusi Organisasi sebesar 23 persen, dan perspektif terendah adalah Orientasi Pengguna sebesar 19 persen. Maka menandakan pegawai sebagai pengguna belum memadai dalam kegiatan untuk masa yang akan datang. Kemampuan dan keahlian pegawai masih memiliki keterbatasan dengan sejumlah kendala dalam mengorganisasikan sistem secara tepat. Maka dari itu perlu untuk meningkatkan lagi kompetensi dan keahlian dalam pelatihan yang diberikan. Dan juga kepuasan dalam menggunakan aplikasi sistem informasi perlu ditingkatkan lagi sehingga mampu menghadapi perubahan-perubahan yang akan datang.
\end{abstract}

Kata Kunci: IT Balanced Scorecard; Sistem Informasi Pegawai; Pengukuran Kerja

Abstract-The public works office of Maluku province is one of the public bodies that has the task of carrying out the affairs of the local government. The purpose of the research is to find out the extent of contribution and utilization through IT applications in supporting employee performance needs. This study uses IT Balanced Scorecard method as a means of measuring clearly, monitoring and optimizing the realization of business values or benefits and benefits of Information Technology where IT Balanced Scorecard has 4 perspectives (Organizational Contribution Perspective, User Orientation Perspective, Operational Excellence Perspective, and Future Orientation Perspective). The research method that will be used in The Measurement of Performance of Public Works Service Employees is mixed methods. In this study, data collection was obtained through interviews, observations, and dissemination of questionnaires to a selected number of respondents based on their abilities and relevant to their work. This study showed the measurement value of Organizational Contribution by 23 percent, User Orientation by 19 percent, Operations by 21 percent, and Future Orientation by 20 percent and for the average result of the IT Balanced Scorecard value is 85 percent. In the employee measurement results, the highest perspective is organization contribution by 23 percent, and the lowest perspective is User Orientation by 19 percent. Thus, it indicates that the employee as a user is not adequate in the activities for the future. The ability and expertise of employees still have limitations with a number of obstacles in organizing the system appropriately. Therefore, it is necessary to improve the competence and expertise in the training provided. And also satisfaction in using information system applications need to be improved again so as to be able to face the changes to come.

Keywords: IT Balanced Scorecard; Employees Information System; Work Measurement

\section{PENDAHULUAN}

Teknologi Informasi (TI) membutuhkan penyelarasan oleh organisasi atau perusahaan agar informasi dalam organisasi atau perusahaan tersebut mendukung tujuan organisasi atau perusahaan, sumber daya digunakan secara tepat dan bertanggung jawab serta risiko teknologi informasi dapat dikelola secara tepat. Ketika organisasi atau perusahaan mampu mengerti dan menyelaraskan serta mengimplementasikan teknologi informasi dalam kegiatannya, maka organisasi maupun perusahaan akan berkembang dengan baik dan sukses. IT BalancedScorecard merupakan salah satu cara yang efektif untuk membantu penyelarasan TI. Tujuannya adalah menyediakan kunci mengenai tujuan strategi TI, menunjukkan efektifitas dan nilai tambah dari TI dan mengkomunikasikan kinerja, resiko dan kemampuan TI. IT Balanced Scorecard telah diadopsi secara luas penggunaannya dalam mengukur kinerja bisnis dan industri, pemerintahan, dan organisasi nirlaba. Metode ini pertama kali diperkenalkan oleh Kaplan dan Norton. IT Balanced Scorecard sendiri merupakan alat konstruktif dengan memfokuskan kepada upaya pengembangan secara konstan. IT Balanced Scorecard menyediakan pemaparan dan ulasan yang bersifat menyeluruh dan terstruktur sehingga setiap manajer yang saling berhubungan dapat terus memantau perkembangan setiap aspek dari strategi penerapan TI. IT Balanced Scorecard mempunyai 4 Perspektif untuk mengukur kinerja pegawai diantaranya, Perspektif Kontribusi 
Organisasi, Perspektif Orientasi Pengguna, Perspektif Keunggulan Opersional, dan Persepktif Orientasi Masa Depan (Arofah, N., Sholiq, \& Nisafani, A. S. 2012) [1].

Dinas pekerjaan umum yang merupakan perpanjangan tangan dari pemerintah pusat yakni kementrian pekerjaan umum, kehadirannya sangat memberi warna terhadap pelayanan publik. Dinas pekerjaan umum provinsi Maluku merupakan salah satu badan publik yang mempunyai tugas melaksanakan urusan pemerintah daerah yang memiliki visi yaitu, terwujudnya infrastruktur pekerjaan umum melalui dukungan permukiman, prasarana dan sasaran yang handal berbasis penataan ruang dan gugus pulau menuju pembangunan yang berkualitas dan berkelanjutan, serta misi yaitu, 1) Mewujudkan penataan ruang sebagai acuan matra spasial dari pembangunan daerah dan keterpaduan pembangunan infrastruktur pekerjaan umum dan permukiman berbasis penataan ruang dan gugus pulau secara berkelanjutan, 2) Mengembangkan dan pengelolaan prasarana sumber daya air yang berkelanjutan dalam rangka mendukung pangan serta mengurangi resiko daya rusak air, 3) Mewujudkan jaringan jalan yang panjang yang mantap, berkelanjutan dengan mobilitas, aksebilitas dan berkeselamatan dalam rangka pengembangan wilayah serta pertumbuhan ekonomi, 4) Meningkatkan kualitas lingkungan permukiman yang layak huni dan produktif melalui pembinaan dan pengembangan infrastuktur permukiman yang terpadu, andal, dan berkelanjutan menuju masyarakat Maluku yang berkualitas dan sejahterah 5) Meningkatkan kinerja jasa konstruksi menuju industri konstruksi daerah yang kompetitif dan inovasi menuju persaingan pasar bebas, 6) Mewujudkan sumber daya aparatur pekerjaan umum yang memiliki integritas dalam menunjang manajemen tata kelola pemerintahan yang baik (good govermance) 7) Meningkatkan pengujian dan operasional peralatan dalam mendukung pembangunan infrastuktur pekerjaan umum yang berkualitas.

Pengukuran terhadap kinerja organisasi merupakan hal yang sangat penting. Dengan melakukan pengukuran kinerja, maka dapat diketahui informasi mengenai kinerja dan faktor-faktor yang mempengaruhi kinerja. Dalam penelitian ini tidak hanya sekedar mengukur kinerja aplikasi TI, tetapi juga membahas mengenai sisi implikasi pada aspek manajerial dan rekomendasi masing-masing perspektif berdasarkan indikator tujuan dan kinerjanya. Tujuan penelitian untuk mengetahui sejauhmana kontribusi dan pemanfaatan melalui aplikasi TI dalam menunjang kebutuhan sistem informasi pegawai. Sasaran penelitian lebih kepada kesiapan dalam memberikan manfaat berupa kemudahan dan ketersediaan informasi untuk setiap bagian proses agar sesuai kebutuhan sistem informasi pegawai yang masih membutuhkan perbaikan dan penyempurnaan.

Penelitian yang dilakukan oleh Murry Albert Agustin Lobo (2016) berjudul "Perencanaan Strategis Sistem Informasi Menggunakan IT Balanced Scorecard: studi kasus PT. Satya Mitra Sejahtera"[2] menjelaskan bagaimana penggunaan IT Balanced Scorecard untuk perencanaan strategis dalam merumuskan perencanaan strategis sistem informasi PT Satya Mitra Sejahtera berdasarkan 4 perspektif yang terdapat dalam IT Balanced Scorecard. Hasil dari penelitian ini adalah perlu dirumuskan tujuan dan profil SI/TI yang sesuai dengan kebutuhan perusahaan guna memenuhi kebutuhan perusahaan dalam mencapai tujuan dan menghadapi tantangan masa depan. Sasaran dan porfil SI/TI dalam organisasi harus mengacu pada visi dan misi PT Satya Mitra Sejahtera agar implementasi SI/TI dalam organisasi dapat memenuhi tujuan perusahaan. Maka perlu dilakukan analisa gap antara situasi saat ini dan situasi yang diharapkan dalam rangka mengembangkan solusi IT bagi perusahaan.

Perbedaan dari penelitian yang telah dilakukan bukanlah mengukur atau menganalisis perusahaan, tetapi lebih kepada instansi pemerintahan. Pada penelitian ini dengan judul "Pengukuran Kinerja Pegawai Dinas Pekerjaan Umum Provinsi Maluku Dalam Pemanfaatan Sistem Informasi Dengan Menggunakan IT Balanced Scorecard" berfokus pada kinerja pegawai dalam pemanfaatan sistem informasi di suatu instansi apakah sudah sesuasi dengan perkembangan TI dimasa sekarang dan juga dapat dijadikan sebagai kontribusi dalam implementasi TI pada instansi tersebut, khususnya dalam pencapaian tujuan untuk masa yang akan datang.

\section{METODE PENELITIAN}

\subsection{Tahapan Penelitian}

Metode penelitian yang akan digunakan dalam Pengukuran Kinerja Pegawai Dinas Pekerjaan Umum adalah metode mixed methods. Penelitian ini merupakan suatu langkah penelitian dengan menggabungkan dua bentuk penelitian yang telah ada sebelumnya yaitu penelitian kualitatif dan penelitian kuantitatif. Menurut Sugiyono (2011), metode penelitian kombinasi (mixed methods) adalah suatu metode penelitian yang mengkombinasikan atau menggabungkan antara metode kuantitatif dengan metode kualitatif untuk digunakan secara bersama-sama dalam suatu kegiatan penelitian, sehingga diperoleh data yang lebih komprehensif, valid, reliable dan obyektif[3].

Pada penelitian ini pengumpulan data diperoleh melalui wawancara, observasi, dan penyebaran kuesioner ke sejumlah responden yang dipilih berdasarkan kemampuan dan relevan dengan pekerjaan mereka. Semua jawaban responden dapat dipertanggungjawabkan kebenarannya. Total responden berjumlah 16 orang, yang terdiri dari Kepala SUB Bagian keuangan, aset, kepegawaian dan umum, Kepala SUB Bagian perencanaan, Kepala Bidang pembinaan teknis jasa kontruksi, Kepala Bidang tata ruang, dan beserta pegawai (3 orang dari masing-masing bidang).Berikut merupakan langkah-langkah penelitian yang dilakukan: 


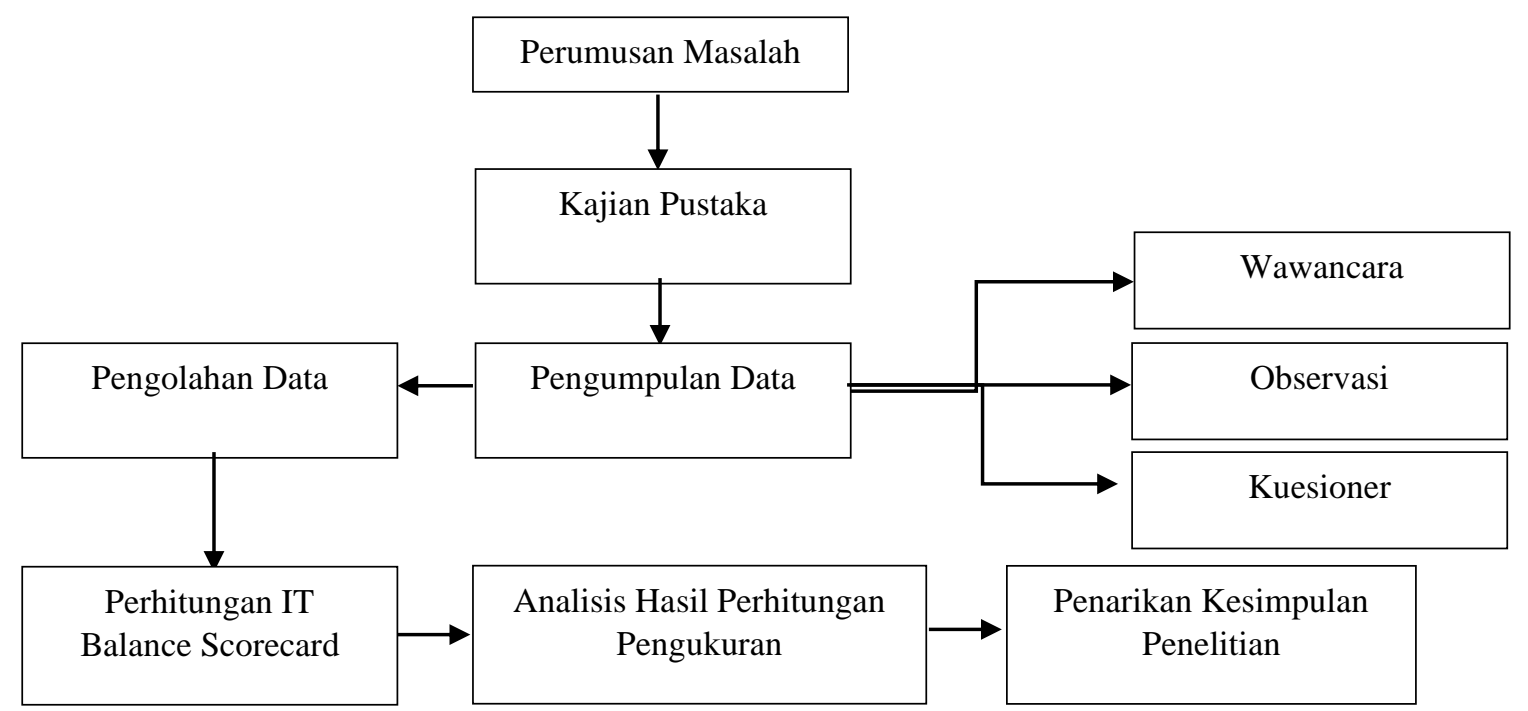

Gambar 1. Langkah-Langkah Penelitian

Untuk tahapan dalam pengukurannya mencakup penyelarasan visi dan misi, penyelarasan strategi TI dengan perspektif IT Balanced Scorecard perancangan sebab akibat, ukuran dan sasaran strategi IT Balanced Scorecard, pengukuran dan hasil pengukuran IT Balanced Scorecard, melakukan pembobotan tujuan strategis pada 4 perspektif IT Balanced Scorecard, dan terakhir melakukan evaluasi hasil pengukuran IT Balanced Scorecard. Selanjutnya semua nilai dari hasi pengukuran akan dimasukkan ke dalam tabel pengukuran kinerja agar dapat dijadikan rekomendasi untuk melakukan perbaikan, mempertahankan dan meningkatkan kinerja di waktu yang akan datang.

Mekanisme perhitungan untuk masing-masing perspektif diawali dengan penentuan nilai sasaran strategis untuk setiap komponen yang dinilai pada bagian ukuran strategis. Nilai sasaran strategis ini berasal dari wawancara dengan Kepala SUB bagian keuangan, aset, kepegawaian dan umum, Kepala SUB bagian perencanaan, Kepala bagian pembinaan teknis jasa kontruksi, dan Kepala bidang tata ruang. Untuk memperoleh nilai kondisi aktual dapat diperoleh dari perhitungan sebagai berikut : total dari perkalian antara jumlah responden yang menjawab 'ya' atau 'tidak' dengan nilai bobot. Nilai bobot 'ya' adalah 2 dan 'tidak' adalah 1 . Kemudian nilai total tersebut dibagi dengan jumlah responden. Kemudian nilai total tersebut dikalikan 50 persen (50 persen karena skala ada 2, maka 100 persen : 2). Selanjutnya untuk mendapatkan nilai pencapaian (hasil yang diperoleh dari kondisi aktual) dengan perhitungan nilai hasil perkalian tersebut dibagi dengan sasaran strategis dan dijadikan dalam bentuk persentase. Untuk menghitung hasil pembobotan tujuan strategis menggunakan perumusan sebagai berikut: (1) Bobot= nilai bobot bersumber dari pihak manajemen, (2) Hasil Tujuan= Hasil Ukuran/100 x Bobot, (3) Hasil Ukuran= hasil rata-rata dari pencapaian pengelohan data dengan bersumber dari masing-masing perspektif[4].

\subsection{Penelitian Terdahulu}

Penelitian pertama berjudul : "Penggunaan IT Balanced Scorecard Untuk Pengukuran Kinerja Teknologi Informasi Pada Stikom Bali”[5] Peneliti membahas tentang masalah divisi IT pada STIKOM yang menangani semua sistem yang ada pada STIKOM Bali seperti aplikasi untuk mahasiswa seperti aplikasi untuk akademik mahasiswa, e-learnin e-KRS. Selain itu juga menangani aplikasi yang diperuntukkan bagi dosen dan bagian administrasi yang ada. Dan pada saat itu STIKOM Bali belum ada pengukuran kinerja teknologi informasi untuk mengetahui kontribusi divisi IT dalam pencapaian tujuan perusahaan. Berdasarkan hal tersebut, pada penelitian ini dilakukan pengukuran kinerja divisi IT menggunakan IT Balanced Scorecard. Berdasarkan target strategis dan inisiatif strategis, maka rekomendasi perbaikan kinerja bagian pengembangan sistem informasi dapat dilihat dengan memperbaiki beberapa sasaran strategis yang nilai target capaiannya dibawah 80 persen seperti pengembangan SDM IT.

Penelitian kedua yang berjudul "Penerapan IT Balanced Scorecard Dalam Penyusunan Peta Strategi Dinas Pertanian Tanaman Pangan (Studi Kasus: Dinas Pertanian Tanaman Pangan Kabupaten Tasikmalaya)"'[6] oleh Bayu Rijal Fadlilah Zein, Aradea dan Husni Mubarok, Universitas Siliwangi Tasikmalaya. Tujuan dari penelitian ini yaitu akan dibangun suatu pedoman berupa usulan peta strategi Teknologi Informasi (TI), yang bersumber dari sasaran strategis bisnis Dinas Pertanian Tanaman Pangan, guna menyelaraskan peranan dan strategi Sistem Teknologi Informasi (STI) yang dimiliki dengan proses bisnis yang berjalan. Setelah dilakukan analisis pada diagram matriks SWOT, maka posisi Dinas Pertanian Tanaman Pangan Kabupaten Tasikmalaya diketahui pada kuadran I. Pada kuadran I (SO Strategi), strategi umum yang dapat dilakukan adalah menggunakan kekuatan Dinas Pertanian Tanaman Pangan Kabupaten Tasikmalaya untuk mengambil setiap keunggulan pada kesempatan yang ada.Telah dibuat usulan peta strategi TI dan rencana 
strategis yang bersumber dari sasaran strategis Dinas Pertanian Tanaman Pangan Kabupaten Tasikmalaya guna menyelaraskan peranan dan strategi teknologi informasi yang dimiliki dengan proses bisnis yang berjalan. Peta strategi TI yang disusun telah dipetakan kedalam CSF dan KPI, untuk memastikan bahwa turunan visi dan misi Dinas Pertanian Tanaman Pangan Kabupaten Tasikmalaya dapat diterapkan menjadi kegiatan sehari-hari.

Dari kedua penelitian terkait di atas terdapat persamaan yaitu, kedua penelitian tersebut membahas tentang pengukuran kinerja Teknologi Informasi serta penyusunan peta sebagai pedoman strategi IT dalam organisai terutama untuk mencapai tujuan jangka panjang dan kedua penelitian tersebut menggunakan framework IT Balanced Scorecard. Menurut peneliti, literature review yang memiliki korelasi yang sama dengan penelitian ini adalah literature review pertama, karena dilihat dari judul, tujuan penelitian, proses pengambilan data (wawancara), yang mana sama dengan penelitian ini, dan diperkuat dengan menggunakan teknik pengambilan data menggunakan kuesioner. Tujuan dari penelitian terkait pertama yaitu mengukur kinerja pegawai dalam memanfaatkan SI dan TI dan harapannya, semua pegawai dapat, memaksimalkan kinerjanya dan siap memberikan kualitas layanan TI yangbaik. Hanya saja yang membedakan dari penelitian ini untuk literature riview yang kedua lebih fokus menentukan strategi yang cocok untuk Kantor Dinas Pertanian Tanaman Pangan Kabupaten Tasikmalaya yang didasarkan pada hasil dari analisis faktor internal dan analisis faktor eksternal juga analisis SWOT.

\subsection{Konsep Balanced Scorecard}

Kaplan dan Norton (1992) merancang Balanced Scorecard sebagai satu set langkah-langkah yang memberikan pandangan yang cepat namun komprehensif kepada manajemen puncak. Balanced Scorecard meliputi ukuran finansial yang menunjukkan suatu hasil dari tindakan yang telah diambil.Balanced Scorecard juga melengkapi ukuran finansial dengan ukuran operasional pada kepuasan konsumen, proses internal, dan aktivitas perbaikan dan inovasi perusahaan.

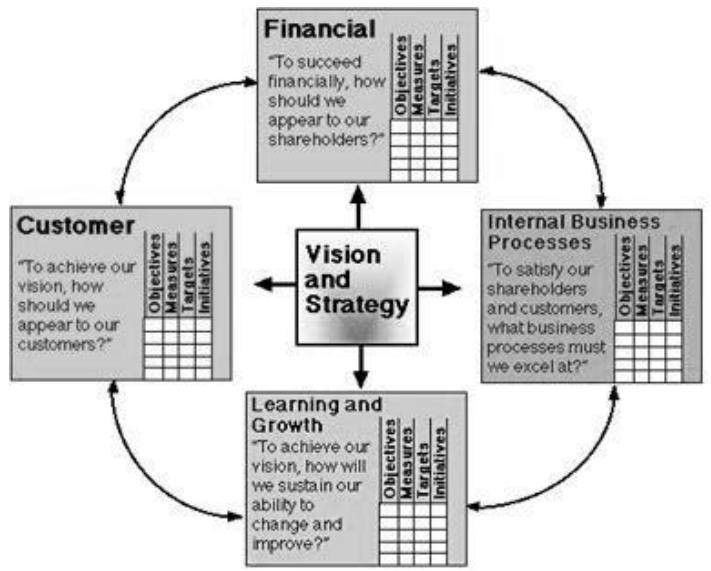

Gambar 2. Kerangka Kerja Balanced Scorecard Adapted from Robert S. Kaplan and David P. Norton, "Using the Balanced Scorecard as a Strategic Management System," Harvard Business Review (2007)[7]

\subsection{IT Balanced Scorecard}

Pada tahun 1997, Balanced Scorecard (BSC) diadopsi Van Grembergen dan Van Bruggen untuk digunakan pada Organisasi Departemen Teknologi Informasi. Mereka berpandangan bahwa Departemen Teknologi Informasi merupakan penyedia layanan internal maka perspektif yang digunakan harus diubah dan disesuaikan. Dengan melihat bahwa pengguna mereka adalah pegawai internal dan kontribusi mereka dinilai berdasarkan pandangan pihak manajemen mak

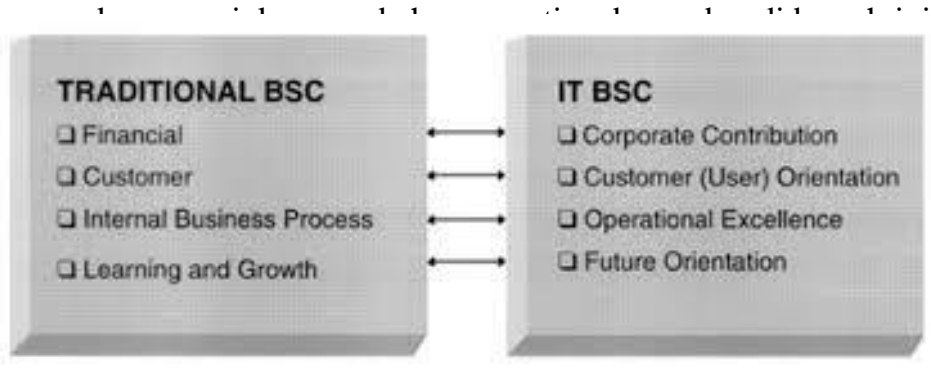

Gambar 3. Perubahan Perspektif BSC Tradisional menjadi IT balanced Scorecard

IT Balanced Scorecard terdiri dari 4 perpektif. Perspektif Kontribusi Organisasi(Corporate Contribution)ini mengevaluasi kinerja TI berdasarkan pandangan dari manajemen eksekutif. Perspektif Orientasi pengguna (User Orientation) yang mengevaluasi kinerja TI berdasarkan cara pandang pengguna bisnis (pelanggan) dan lebih jauh lagi pelanggan unit yang ada. Dengan perspektif ini, maka perusahaan atau oragnisasi 
dapat menyelarasakan sebagai ukuran pelanggan, seperti kepuasan, maupun loyalitas.Perspektif Keunggulan Operasional (Operational Exellence) ini menilai kinerja TI berdasarkan efektivitas dan efisiensi dari prosesproses TI yang dinilai oleh pihak manajemen. Perspektif Orientasi Masa Depan (Future Orientation) ini menilai kinerja TI berdasarkan cara pandang departemen TI itu sendiri terhadap tantangan di masa depan yang utamanya adalah menyiapkan personil TI yang profesional untuk menghadapi tantang masa depan. Masing-masing perspektif ini harus diterjemahkan ke dalam langkah-langkah yang sesuai dalam menilai situasi saat ini. Penilain ini perlu diulang secara berkala dan selasar dengan tujuan yang di tetapkan sebelumnya.

\section{HASIL DAN PEMBAHASAN}

Berikut tabel penyelarasan strategi TI yang di gunakan

Tabel 1. Penyelarasan (penyesuaian) Strategi TI Dengan Perspektif IT balanced Scorecard

\begin{tabular}{|c|c|c|}
\hline IT balanced Scorecard & Strategi & Tujuan Strategi \\
\hline $\begin{array}{l}\text { Perspektif Kontribusi } \\
\text { Organisasi }\end{array}$ & 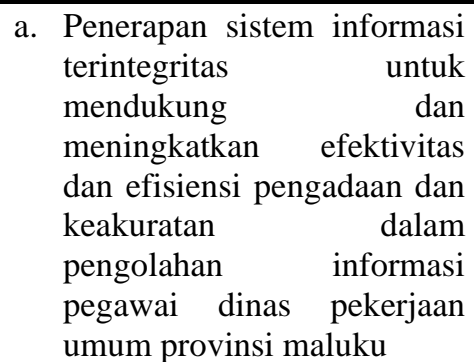 & $\begin{array}{l}\text { a. Efektivitas dan efisiensi finansial. } \\
\text { b. Efisiensi proses penggunaan aplikasi } \\
\text { sistem informasi pegawai }\end{array}$ \\
\hline $\begin{array}{l}\text { Perspektif Orientasi } \\
\text { Pengguna }\end{array}$ & $\begin{array}{l}\text { a. Memberikan pelatihan } \\
\text { kepada semua pegawai } \\
\text { dalam menerapkan TI untuk }\end{array}$ & $\begin{array}{l}\text { a. Meningkatkan kompetensi dan } \\
\text { keahlihan semua pegawai dalam } \\
\text { menggunakan TI secara optimal }\end{array}$ \\
\hline & 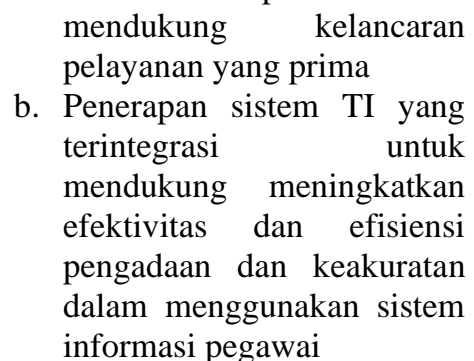 & $\begin{array}{l}\text { b. Meningkatkan kepuasan pengguna } \\
\text { dalam menggunakan aplikasi sistem } \\
\text { informasi pegawai }\end{array}$ \\
\hline Perspektif Operasional & $\begin{array}{l}\text { Memberikan pelatihan kepada } \\
\text { pegawai dalam menerapkan TI } \\
\text { untuk mndukung pelayanan } \\
\text { yang baik kepada masyarakat. }\end{array}$ & $\begin{array}{l}\text { a. Meningkatkan kelayakan sistem } \\
\text { berbasis TI. } \\
\text { b. Menghasilkan kualitas informasi yang } \\
\text { lebih baik. } \\
\text { c. Meningkatkan kualitas keamanan } \\
\text { sistem informasi. }\end{array}$ \\
\hline $\begin{array}{l}\text { Perspektif Orientasi } \\
\text { Masa Depan }\end{array}$ & $\begin{array}{lr}\text { a. } & \begin{array}{l}\text { Penerapan sistem TI yang } \\
\text { terintegritas }\end{array} \\
\text { untuk } \\
\text { mendukung } \\
\text { meningkatkan efektivitas } \\
\text { dan efisiensi pengadaan dan } \\
\text { keakuratan } r \text { informasi } \\
\text { pegawai dinas pekerjaan } \\
\text { umum provinsi maluku. } \\
\text { b. Memberikan pelatihan } \\
\text { kepada pegawai dalam } \\
\text { penerapan TI mendukung } \\
\text { pelayanan yang baik. }\end{array}$ & $\begin{array}{l}\text { a. Meningkatkan kompetensi TI dan } \\
\text { kemampuan pegawai. } \\
\text { b. Meningkatkan pengembangan sistem } \\
\text { dengan pemanfaatan TI yang baru. }\end{array}$ \\
\hline
\end{tabular}

Ukuran strategis diperoleh dari penjabaran masing-masing tujuan strategis IT balanced Scorecard sehingga menjadi beberapa ukuran penting. Setiap ukuran strategis harus memiliki suatu sasaran strategis. Selanjutnya melakukan proses pengukuran untuk menilai kinerja aplikasi sistem informasi pegawai. Setelah mengetahui ukuran strategis dan sasaran strategis dari tiap perspektif IT balanced Scorecard, maka perhitungan IT balanced Scorecard dapat dilakukan. Perhitungan dilakukan dengan tujuan untuk melakukan perbandingan tiap tujuan strategis dengan kondisi yang ada pada organisasi saat ini. Adapun gambaran umum responden dalam penelitian ini adalah Kepala SUB Bagian keuangan, aset, kepegawaian dan umum, Kepala SUB Bagian 
perencanaan, Kepala Bidang pembinaan teknis jasa kontruksi, Kepala Bidang tata ruang, dan beserta pegawai (3 orang dari masing-masing bidang). Jumlah pembagian kuesioner berjumlah 16 dan yang dikembalikan berjumlsh 16. Berikut ini merupakan rekaptulasi perhitungan evaluasi hasil mengenai pemanfaatan aplikasi TI untuk masing-masing perspektif IT balanced Scorecard.

Tabel 2. Hasil Pengukuran Kinerja Sistem Informasi Pegawai

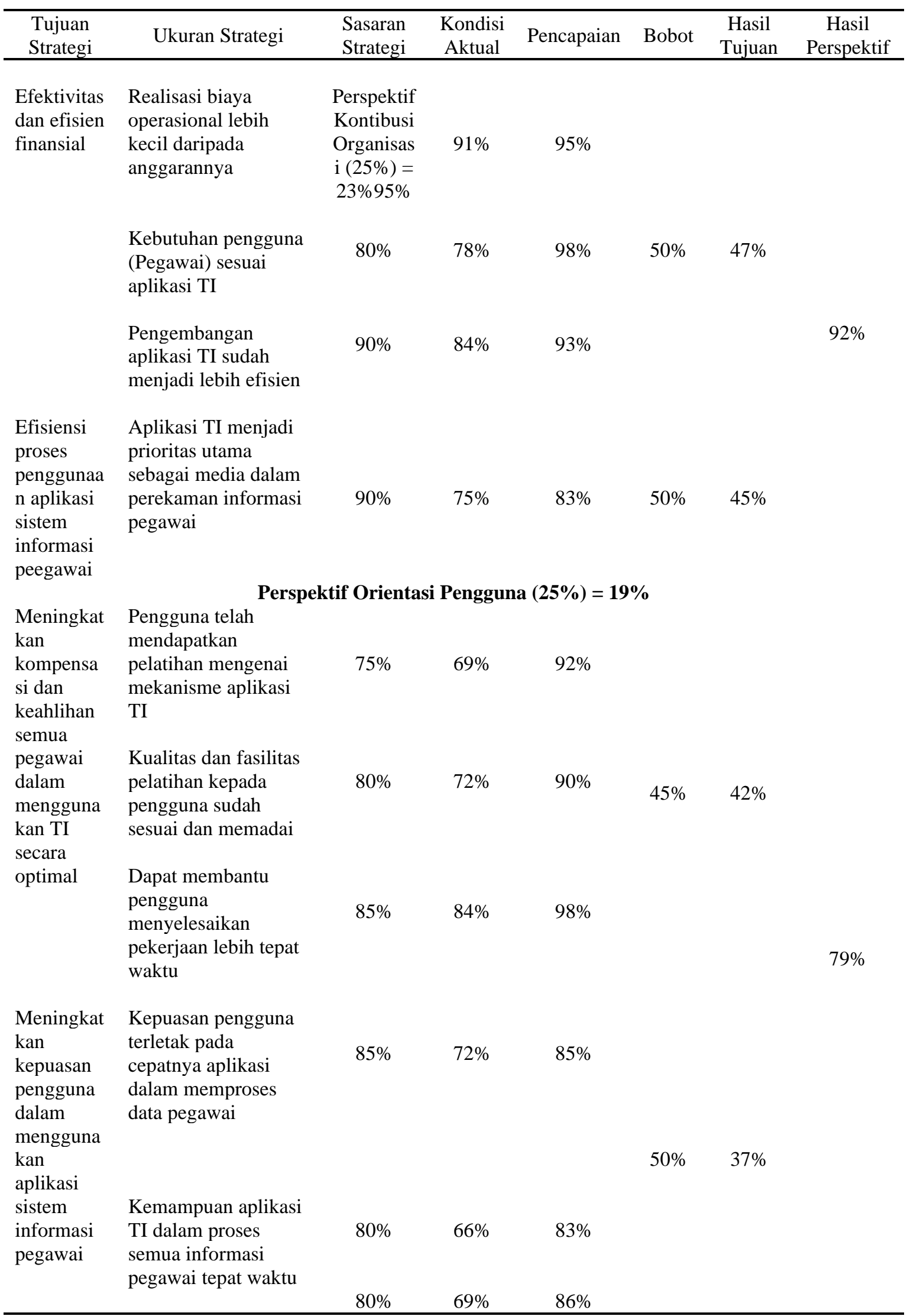




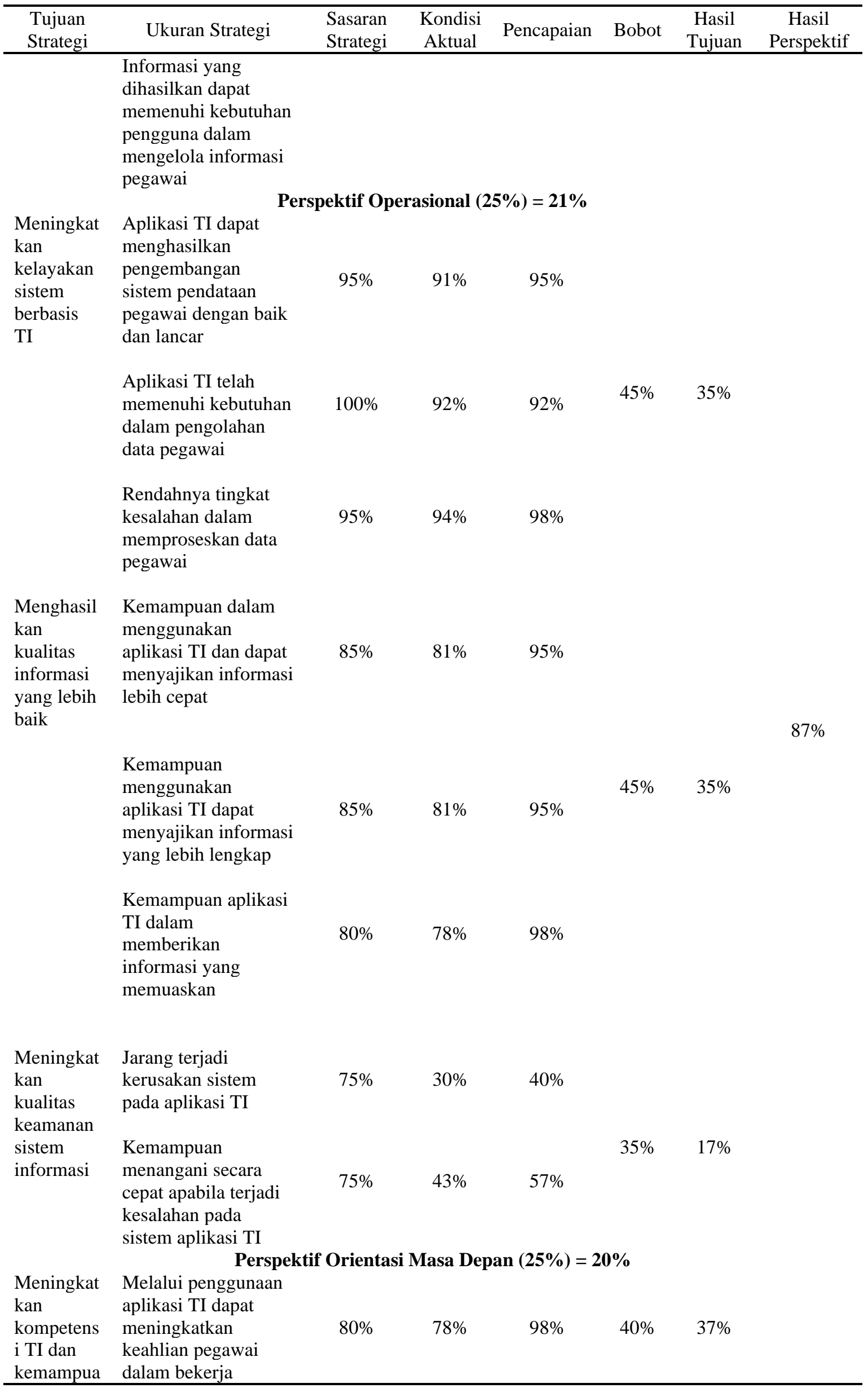




\begin{tabular}{|c|c|c|c|c|c|c|c|}
\hline $\begin{array}{c}\text { Tujuan } \\
\text { Strategi }\end{array}$ & Ukuran Strategi & $\begin{array}{l}\text { Sasaran } \\
\text { Strategi }\end{array}$ & $\begin{array}{c}\text { Kondisi } \\
\text { Aktual }\end{array}$ & Pencapaian & Bobot & $\begin{array}{c}\text { Hasil } \\
\text { Tujuan }\end{array}$ & $\begin{array}{c}\text { Hasil } \\
\text { Perspektif }\end{array}$ \\
\hline \multirow[t]{4}{*}{ n pegawai } & & & & & & & \\
\hline & $\begin{array}{l}\text { Penggunaan aplikasi } \\
\text { TI dapat mengurangi } \\
\text { kesalahan pengguna }\end{array}$ & $100 \%$ & $91 \%$ & $91 \%$ & & & \\
\hline & $\begin{array}{l}\text { Kemudahan dalam } \\
\text { mendapatkan } \\
\text { informasi pegawai }\end{array}$ & $100 \%$ & $88 \%$ & $88 \%$ & & & \\
\hline & $\begin{array}{l}\text { Kemampuan aplikasi } \\
\text { TI menghasilkan } \\
\text { informasi menjadi } \\
\text { lebih cepat dan sesuai } \\
\text { kebutuhan }\end{array}$ & $85 \%$ & $81 \%$ & $95 \%$ & & & \\
\hline \multirow{4}{*}{$\begin{array}{l}\text { Meningkat } \\
\text { kan } \\
\text { pengemba } \\
\text { ngan } \\
\text { sistem } \\
\text { dengan } \\
\text { pemanfaat } \\
\text { an TI yang } \\
\text { baru }\end{array}$} & $\begin{array}{l}\text { Kemampuan } \\
\text { melakukan } \\
\text { peningkatan sistem } \\
\text { dan pemanfaatan } \\
\text { aplikasi TI }\end{array}$ & $85 \%$ & $81 \%$ & $95 \%$ & & & \\
\hline & $\begin{array}{l}\text { Dinas pekerjaan } \\
\text { Umum selalu } \\
\text { mengikuti } \\
\text { perkembangan } \\
\text { aplikasi TI dimasa } \\
\text { depan }\end{array}$ & $95 \%$ & $92 \%$ & $96 \%$ & $45 \%$ & $43 \%$ & $80 \%$ \\
\hline & $\begin{array}{l}\text { Pegawai } \\
\text { mendapatkan } \\
\text { pelatihan tentang } \\
\text { penggunaan aplikasi } \\
\text { TI }\end{array}$ & $95 \%$ & $94 \%$ & $98 \%$ & & & \\
\hline & $\begin{array}{l}\text { Pelatihan dapat } \\
\text { meningkatkan } \\
\text { pengetahuan pegawai } \\
\text { dalam menggunakan } \\
\text { aplikasi TI }\end{array}$ & $100 \%$ & $96 \%$ & $99 \%$ & & & \\
\hline
\end{tabular}

Nilai IT Balanced Scorecard $=\mathbf{8 5} \%$

Tabel 2 adalah pengukuran terhadap kinerja pegawai dalam pemanfaatan sistem informasi, dengan cara mengkumpulan semua data dari 2 sub bagian dan 3 bidang. Setelah data dikumpulkan dan dihitung dari jumlah jawaban dari para respoden, maka selanjutnya akan melalukan perhitungan kinerja terhadap pencapaian sasaran strategis dari masing-masing ukuran strategis. Sasaran strategis ditetapkan oleh peneliti yang telah disetujui oleh Dinas pekerjaan umum. Berikutnya melakukan perhitingan terhadap kondisi aktual dan pencapaian pada masingmasing ukuran strategis. Kondisi aktual merupakan jumlah nilai dari jawaban responden "ya" dan "tidak"dibagi jumlah responden dan dikali dengan 50\%. Dan untuk hasil dari pencapaian didapatkan dari kondisi aktual dibagi sasaran strategis dikalikan 100. Selanjutnya untuk data mengenai pembobotan tujuan strategis didapatkan dari wawancara pihak manajemen IT. Untuk perhitungan selanjutnya merupakan hasil tujuan yang didapat hasil ukuran (rata-rata dari pencapaian) dibagi 100 dan dikalikan bobot, selanjutnya untuk hasil perspektif merupakan penjumlahan dari hasil tujuan. Berikutnya hasil dari masing-masing perspektif (25\%) didapat dari 25 dibagi 100 dikalikan hasil perspektif. Dan hasil akhir nilai IT Balance Scorecard merupakan rata-rata dari hasil perspektif.

Berikut hasil pembobotan tujuan strategis

\section{a. Prespektif Kontribusi Organisasi}

Tujuan strategis efektivitas dan efisien finansial diberi bobot 50 persen dengan hasil ukuran 95 persen dan hasil tujuan 47 persen. Tujuan efisiensi proses penggunaan aplikasi sistem informasi pegawai diberi bobot 50 persen dengan hasil ukuran 91 persen dan hasil tujuan 45 persen. Sehingga didapat hasil pengukuran 
prespektif kontribusi organisasi yaitu 23 persen yang didapat dari 25 persen (masing-masing perspektif diberi 25 persen)/100*hasil perspektif

b. Prespektif Orientasi Pengguna

Tujuan strategis peningkatan kompetensi dan keahlihan dalam menggunakan TI diberi bobot 45 persen dengan hasil ukuran 93 persen dan hasil tujuan 42 persen. Tujuan strategis peningkatan kepuasan dalam menggunakan aplikasi sistem informasi pegawai diberi bobot 50 persen dengan hasil ukuran 85 persen dan hasil tujuan 37 persen. Sehingga didapat hasil pengukuran prespektif orientasi pengguna yaitu 19 persen.

c. Prespektif Keunggulan Operasional

Tujuan strategis peningkatan kelayakan sistam diberi bobot 45 persen dengan hasil ukuran 95 persen dan hasil tujuan 35 persen. Tujuan strategis untuk kualitas informasi yang lebih baik diberi bobot 45 persen dengan hasil ukuran 96 persen dan hasil tujuan 35 persen. Dan ujuan strategi peningkatan kualitas keamanan sistem informasi diberi bobot 35 persen dengan hasil ukuran 49 persen dan hasil tujuan 17 persen Sehingga didapat hasil pengukuran prespektif orientasi pengguna yaitu 21 persen.

d. Prespektif Orientasi Masa Depan

Tujuan strategis peningkatan kompetensi TI dan kemampuan pegawai diberi bobot 40 persen dengan hasil ukuran 93 persen dan hasil tujuan 37 persen. Tujuan strategis peningkatan pengembangan sistem dengan teknologi baru diberi bobot 45 persen dengan hasil ukuran 97 persen dan hasil tujuan 43 persen. Sehingga didapat hasil pengukuran prespektif orientasi masa depan yaitu 20 persen.

Dari nilai pengukuran menunjukkan bawah masing-masing perspektif mendeskripsikan tidak ada yang memiliki maksimal 25 persen. Berikut kutipan pengambilan data (wawancara) dan hasil nilai dari masingmasing perspektif dan selisi nilai:

\section{Perspektif Kontribusi Organisasi}

Setiap organisasi harus berusaha keras untuk mencapai visi dan misi organisasi agar organisasi memiliki tujuan yang jelas. Visi dan misi yang ada diharapkan menjadi indikator arah masa depan yang baik. Visi dan misi tersebut menjadi acuan agar organisasi dapat lebih memahami ke arah mana mereka harus melangkah dan apa yang akan dihasilkan.

Menurut bapak Daniel selaku pegawai divisi IT, Tidak hanya dengan dengan omongan semata, tetapi juga melalui kerja keras dan tindakan spesifik dari pegawai untuk memenuhi visi dan misi, lalu bagaimana pegawai divisi IT dapat bekerja keras untuk mencapai visi dan misi perusahaan? Berikut tanggapan Pak Daniel Siwabessy sebagai pegawai divisi IT:

"Umm... ya tentu kita harus patuh pada aturan dan berusaha menjaga kenyamanan dan kepuasan orang-orang yang bekerja sama dengan kita. Intinya, reputasi baik adalah yang pertama ya non, jadi kita selalu lakukan yang terbaik untuk reputasi baik kita, yang tentu saja akan mengarah pada pekerjaan kita sebagai pegawai.”

Mengetahui visi dan misi dari Dinas Pekerjaan Umum, pegawai Dinas Pekerjaan Umum mengakui kinerja yang baik tentu akan membuahkan hasil yang baik. Tentu saja, mereka selalu berusaha dalam kemampuan mereka sendiri. Apalagi Dinas Pekerjaan Umum merupakan perpanjangan tangan dari pemerintah pusat, kehadirannya sangat membantu pelayanan publik.

Pegawai Dinas Pekerjaan Umum menyadari bahwa selama ini perkembangan teknologi informasi berkembang pesat dan persaingan yang semakin ketat. Teknologi informasi merupakan aset penting bagi kemajuan perusahaan.Oleh karena itu, sebagai yang melayani kebutuhan masyarakat juga harus mengikuti Kembangkan dan persiapkan untuk itu. Inovasi baru di bidang teknologi informasi. Melalui pemanfaatan teknologi, pekerjaan sehari-hari pegawai semakin mudah. Bapak Daniel, mengatakan:

"Nah .. Kami sangat menyadari perkembangan teknologi, terutama perkembangan internet. Sekarang dunia telah melakukan semua pekerjaan dengan bantuan teknologi, bukan begitu? dan kami juga menyadari bahwa keberadaan teknologi informasi memang sangat membantu pekerjaan kami”

Dapat disimpulkan perspektif kontribusi perusahaan menjelaskan bagaimana perwujudan visi dan misi Dinas Pekerjaan Umum mendorong perkembangan yang dimana melalui pegawainya. Pekerjaan yang dilakukan perusahaan dalam mewujudkan visi dan misinya. Dari perspektif kontibusi organisasi sebesar 23 persen. Memiliki selisih 2 persen ini dapat dikatakan sangat baik, karena mengedepankan kualitas layanan sesuai dengan kemampuannya sesuai dengan visi dan misinya.

\section{Perspektif Orientasi Pengguna}

Dari perspektif ini, pengguna adalah pegawai Dinas pekerjaan umum itu sendiri. Dijelaskan dari segi kontribusi perusahaan, pegawai Dinas pekerjaan umum tentunya akan menggunakan sistem aplikasi untuk bekerja.

Melihat dari tugas-tugas yang dikerjakan oleh para pegawai yang akan berpengaruh ke kinerja pegawai itu sendiri, maka kemampuan pegawai dalam menerapkan sistem informasi, bapak Daniel mengatakan:

"Kemampuan pegawai di Dinas pekerjaan umum terbilang cukup baik dalam menerapakan, menggunakan maupun mengoperasikan sistem-sitem IT yang ada.”

Jika dilihat dari jawaban pak Daniel dapat dibilang bahwa adanya pelatihan atau training sehingga pegawai dapat menerapkan Teknologi Informasi yang ada. Pak Daniel mengatakan: 
“Untuk pelatihan atau training sendiri tentu ada, karena bisa dikatakn itu juga termasuk dalam program pemerintah.”

Berdasarkan cara pandang dari IT Balanced Scorecard, Pengaruh kontrol dan pengawasan kinerja dari pihak terkait juga akan sangat membantu kinerja yang baik khususnya bagi pegawai.Tetapi kenyataannya, nilai untuk perspektif orientasi pengguna sebesar 19 persen. Merupakan nilai perspektif terendah, memiliki selisih sebesar 6 persen. Nilai tersebut lebih besar dari batas toleransi 5 persen. Maka dari itu perlu diperhatikan lagi dalam pemanfaatan sistem informasi. Dan juga perlu adanya peningkatan kompensasi dan keahlihan, serta peningkatan kepuasan pengguna dalam menggunakan aplikasi sistem informasi pegawai.

\section{Perspektif Operasional}

Evaluasi kinerja pegawai berdasarkan perspektif TI itu sendiri merupakan bagian dari pembahasan dalam perspektif operasional. Kinerja pegawai sangat mempengaruhi bagaimana kemajuan perusahaan di masa depan yang dapat dilihat dari proses penyelesaian pekerjaan yang dibutuhkan publik dan aturan dalam proses kerja.

Untuk Dinas Pekerjaan Umum yang bisa dikatakan cukup sibuk dalam penyelesaian kebutuhan publik, pegawai menyelesaikan perkerjaan yang diminta dalam memanfaatkan waktu bisa dibilang cukup baik. Hal ini juga dikatakan oleh pak Daniel:

"Pegawai disini juga memiliki displin waktu yang dapat saya katakan baik untuk penyelesaian tugastugas, maupun permintaan dari masyarakat”

Seperti yang sudah dikatakan bahwa kemajuan Dinas Pekerjaan Umum dimasa depan dilihat dari proses penyelesaian pekerjaan. Untuk proses penyelesaian pekerjaan perlu didukung oleh sistem yang tentunya tidak ada kendala. Lalu bagaimana pemeliharan dalam meningkatkan kelayakan sistem? Bapak daniel mengatakan:

“Kami melakukan maintenacee atau pemiliharan secara berkala dengan menggunakan outsourching ataupun pihak pemerintah"

Dapat disimpulkan secara peningkatan kelayakan sistem dalam menyelesaikan pekerjaan sudah baik. Dan juga menghasilkan kualitas informasi, serta peningkatan kualitasi keamanan aset, informasi serta data-data sudah dikatakan cukup baik. Perspektif operasional mendapatkan nilai sebesar 21 persen dan memiliki selisi 4 persen.

\section{Perspektif Masa depan}

Ketika berbicara tentang orientasi masa depan, knowledge SDM merupakan salah satu aset yang paling berpengaruh terhadap pertumbuhan dan kecepatan sebuah organisasi atau perusahaan. Untuk hal yang baru pasti selalu ada hal seperti pelatihan atau training. Tidak hanya untuk pegawai baru yang bergabung, tetapi juga untuk semua implementasi sistem baru atau pun penggunaan aplikasi yang baru baik untuk pegawai baru atau pegawai lama. Tanggapan disampaikan oleh pak Daniel, demikian:

"Untuk pelatihan atau training terhadap pegawai baru, seluruh pegawai yang baru bergabung dengan Dinas Pekerjaan Umum akan mendapatkan pelatihan. Apalagi jika ada implementasi sistem atau perangkat baru. Tidak hanya untuk pegawai baru, pegawai lama akan selalu dilatih untuk sesuatu yang baru.”

Untuk persepktif yang terakhir disimpulkan bahwa peningkatan kapabilitas TI dan kemampuan pegawai untuk mengembangkan sistem dalam menggunakan aplikasi TI yang baru. Sistem informasi kepemilikan pegawai merupakan hal yang sangat penting dan dapat digumakan sebgai media untuk meningkatkan kapabilitas dan daya saing untuk ke depannya. Perspektif masa depan mendapatkan nilai 20 persen dan memiliki selisih 5 persen

Setelah dilakukan pengukuran kinerja melalui keempat perspektif yang ada pada IT Balanced Scorecard, maka dapat dilakukan evaluasi hasil pengukuran terhadap hasil rata-rata pencapaian yang diperoleh dari masingmasing perspektif. Perspektif kontribusi organisasi memiliki nilai 92 persen, yang dimana pencapaian ini berada pada tingkat yang sangat baik. Ini terjadi karena pengefektivan dan pengefisien produktivitas pegawai sesuai dengan rencana. Perspektif orientasi pengguna memiliki nilai 79 persen dan berada pada level yang baik. Ini terjadi karena pelatihan pengguna secara teratur dan partisipasi pengguna yang juga terlibat dalam pengembangan sistem yang dapat meningkatkan kemampuan pengguna, terutama dibidang TI, yang akan mengurangi kesalahan dan meningkatkan daya saing. Perspektif operasional memiliki nilai 87 persen yang berada pada level baik. Hal ini terjadi karena adanya dukungan dan pemeliharaan operasional sudah sepenuhnya terlaksanakan. Selanjutnya untuk Perspektif Orientasi Masa Depan memiliki hasil 80 persen terlihat bahwa pencapaian perspektif orientasi masa depan juga berada pada level yang baik[8]. Hal ini terjadi karena terdapat cukup peningkatan terhadap kemampuan terhadap pegawai, dikarenakan Dinas Pekerjaan Umum sering melakukan pelatihan untuk menambah keahlian pegawai di bidang TI. Dan juga dilakukan pengembangan sistem sejalan dengan perkembangan TI untuk pencapaian yang lebih baik di masa yang akan datang.

Penggunaan sistem informasi pegawai mampu memberikan kontribusi terhadap organisasi, mendukung orientasi pengguna, mendukung kegiatan operasional, dan mampu menjadi keunggulan bersaing di masa depan. Hal ini dapat dinilai dari perolehan pengukuran dari masing-masing perspektif yaitu kontribusi organisasi sebesar 92 persen dengan hasil pengukuran dari masing-masing perspektif sebesar 23 persen, orientasi pengguna sebesar 79 persen dengan hasil pengukuran dari masing-masing perspektif sebesar 19 persen, keunggulan operasional sebesar 87 persen dengan hasil pengukuran dari masing-masing perspektif sebesar 21 persen, dan orientasi masa depan sebesar 80 persen dengan hasil pengukuran dari masing-masing perspektif sebesar 20 persen. 


\section{KESIMPULAN}

Berdasarkan hasil analisis dan pengukuran yang telah dilakukan terhadap kinerja pegawai dalam pemanfaatan sistem informasi pada Dinas Pekerjaan Umum Provinsi Maluku menggunakan metode IT balanced scorecard dengan teknik pengumpulan data menggunakan teknik mixed metod yaitu melakukan observasi,wawancara dan kuesioner maka dapat diambil kesimpulan bahwa dengan hasil Perspektif tertinggi adalah kontribusi organisai sebesar 23 persen, yang kedua adalah operasioanal sebesar 21 persen, ketiga adalah orientasi masa depan sebeesar 20 persen dan perspektif terendah adalah orientasi pengguna sebesar 19 persen. Perspektif orientasi pengguna mendapatkan hasil yang terendah dikarenakan kurangnya kepuasaan pegawai. Hal ini disebabkan oleh belum sepenuhnya pelatihan mengenai mekanisme penggunaan TI secara keseluruhan. Maka dari itu perlu untuk meningkatkan lagi kompetensi dan keahlihan dalam pelatihan yang diberikan. Dan juga kepuasan dalam menggunakan aplikasi sistem informasi perlu ditingkatkan lagi sehingga mampu menghadapi perubahanperubahan yang akan datang.

\section{REFERENCES}

[1] A. D. . ZARA, "Penyusunan IT Balanced Scorecard Untuk Pengukuran Pusat Pada Perusahaan Daerah Air Minum (PDAM) Kota Malang."

[2] A. R. Tanaamah and M. Cs, "Perencanaan Strategis Sistem Informasi menggunakan IT Balanced Scorecard ( Studi Kasus : PT . Satya Mitra Sejahtera )," no. September, pp. 1-20, 2016.

[3] Sugiyono, METODE PENELITIAN KOMBINASI (MIXED METHODS). 2014.

[4] E. Anastasia, "Analisis Pengukuran Kinerja Teknologi Informasi Pada PT Pegadaian menggunakan Metode IT Balanced Scorecard (Studi Kasus: PT Pegadaian Cabang Salatiga)," J. Sist. Inf., 2016.

[5] R. Kartika Wiyati STIKOM Bali Jln Raya Puputan no and R. Denpasar, "Penggunaan IT Balanced Scorecard Untuk Pengukuran Kinerja Teknologi Informasi Pada Stikom Bali," J. Sist. dan Inform., vol. 10, no. 1, pp. 120-128, 2015.

[6] B. Rijal, F. Zein, and H. Mubarok, "( Studi Kasus : Dinas Pertanian Tanaman Pangan Kabupaten Tasikmalaya ),” pp. $1-6$.

[7] R. Kaplan and D. Norton, "Using the Balanced Scorecard as a Strategic Management System," Harvard Business Riview, 2007.

[8] S. Kosasi, "Pengukuran Kinerja Aplikasi Electronic General Ledger System dengan IT Balanced Scorecard," pp. 9-10, 2015. 